\title{
Microstructure and wear of iron-based hardfacings reinforced with in-situ synthesized $\mathrm{TiB}_{2}$ particles
}

\author{
M. Kaptanoglu*, M. Eroglu \\ Department of Metallurgical and Materials Engineering, Faculty of Engineering, University of Firat, \\ Elazig, 23000, Turkey
}

Received 10 February 2016, received in revised form 9 June 2016, accepted 10 June 2016

\begin{abstract}
In this study, four hardfacings, reinforced with in-situ synthesized $\mathrm{TiB}_{2}$ particles, were cladded by tungsten inert gas (TIG) welding, applying flux-cored wires with varying Fe-Ti and Fe-B content. Microstructural examination, macrohardness and microhardness measurements and abrasive wear tests were performed. Morphology of $\mathrm{TiB}_{2}$ changed from a small-sized hexagonal and rectangular to a coarse plate-like one with the increasing common proportion of titanium and boron. Accordingly, hardness and wear resistance increased linearly with the changing titanium and boron content in hardfacings.
\end{abstract}

K e y w ord s: $\mathrm{TiB}_{2}$, wear, microstructure, hardfacing, flux-cored wire

\section{Introduction}

Ceramic reinforced metal matrix composites are frequently preferred for applications such as automotive, military and aerospace industry due to their high corrosion strength and wear resistance. Although ceramic reinforced light metal matrix ( $\mathrm{Al}, \mathrm{Ti}$ or $\mathrm{Mg}$ ) composites are being studied intensively, ceramic reinforced ferrous metal matrix composites are also investigated [1-6]. With the addition of ceramicbased particles such as carbides and borides into the iron-based matrix, abrasion resistance and material strength increase [7-9]. For example, steel matrix composites reinforced with ceramic particles as a protection against wear and corrosion are recommended in chemical and processing industries [10 $12]$.

Production cost, difficulties in making the final shape of parts and low ductility are disadvantages of metal matrix composites [13]. Thus, cheaper hardfacings and hardfacings with ductile characteristics have gained a more important role nowadays. Therefore, ceramic-reinforced iron matrix composites have become very important in recent years. For this purpose, hardfacings formed by plasma arc welding and laser welding have frequently been used [14-17]. For example, steel surfaces are deposited by special alloyed elec- trodes to form chromium carbide in coating or weld metal [18].

The studies on titanium diboride $\left(\mathrm{TiB}_{2}\right)$ use in a wide area ranging from cutting edge components to the aerospace industry have been conducted. This material has unique properties such as superior hardness (33 GPa), high elastic modulus (530 GPa), high melting temperature $\left(3000^{\circ} \mathrm{C}\right)$, low density $(4.451$ $\mathrm{g} \mathrm{cm}^{-3}$ ) and high corrosion resistance up to $1400^{\circ} \mathrm{C}$ [19]. Upon the literature review, it was observed that there was no study indicating hardfacing reinforced with $\mathrm{TiB}_{2}$ on steel surface through TIG method by using titanium and boron in the flux-cored wire. Therefore, the purpose of this study was to synthesize the $\mathrm{TiB}_{2}$ ceramic particles in steel matrix and improve the properties of obtained hardfacings. Thus, ferrotitanium and ferroboron were added to core. After production of the flux-cored wire, SAE 1020 steel was coated with the use of flux-cored wires. Microstructural analysis, composition analysis, hardness measurements, and wear tests were performed on coated specimens.

\section{Experimental}

TIG welding method was employed and four dif-

\footnotetext{
*Corresponding author: tel: +90 042423700 00; fax: +90 42424155 26; e-mail address: mkaptanoglu@firat.edu.tr
} 
Table 1. Chemical composition of produced flux-cored wires (wt.\%)

\begin{tabular}{lcccccccccc}
\hline & \multicolumn{1}{c}{ Composition (wt.\%) } \\
\cline { 2 - 10 } No. of flux-cored wire & $\mathrm{C}$ & $\mathrm{Mn}$ & $\mathrm{Si}$ & $\mathrm{S}$ & $\mathrm{P}$ & $\mathrm{Al}$ & $\mathrm{B}$ & $\mathrm{Ti}$ & $\mathrm{Fe}$ \\
\hline Specimen no. 1 & 0.15 & 0.50 & 0.25 & 0.025 & 0.03 & 0.20 & 4 & 10 & Bal. \\
Specimen no. 2 & 0.15 & 0.50 & 0.25 & 0.025 & 0.03 & 0.20 & 6 & 15 & Bal. & B \\
Specimen no. 3 & 0.15 & 0.50 & 0.25 & 0.025 & 0.03 & 0.20 & 8 & 20 & Bal. \\
Specimen no. 4 & 0.15 & 0.50 & 0.25 & 0.025 & 0.03 & 0.20 & 10 & 25 & Bal. \\
\hline
\end{tabular}

Table 2. Chemical composition of SAE 1020 steel, ferroboron, and ferrotitanium (wt.\%)

\begin{tabular}{lccccccccccc}
\hline \multirow{2}{*}{ Material } & \multicolumn{1}{c}{ Composition (wt.\%) } \\
\cline { 2 - 11 } & $\mathrm{C}$ & $\mathrm{B}$ & $\mathrm{Ti}$ & $\mathrm{Mn}$ & $\mathrm{Si}$ & $\mathrm{S}$ & $\mathrm{Al}$ & $\mathrm{P}$ & $\mathrm{Fe}$ \\
\hline Substrate (SAE 1020) & 0.18 & - & - & 0.15 & 0.25 & 0.03 & - & 0.03 & Bal. \\
Ferroboron & 0.24 & 18.1 & - & - & 0.44 & - & 0.06 & 0.02 & Bal. \\
Ferrotitanium & 0.14 & - & 71.71 & - & 0.18 & 0.03 & 1.67 & - & Bal. \\
\hline
\end{tabular}

Table 3. TIG welding parameters (wt.\%)

\begin{tabular}{cccc}
\hline Current $(\mathrm{A})$ & Voltage $(\mathrm{V})$ & Welding rate $\left(\mathrm{mm} \mathrm{s}^{-1}\right)$ & Argon flow $\left(\mathrm{m}^{3} \mathrm{~s}^{-1}\right)$ \\
\hline 120 & 24 & 0.50 & 6 \\
\hline
\end{tabular}

ferent flux-cored wires having a 4-mm diameter were produced to form $\mathrm{TiB}_{2}$ in hardfacings. Table 1 shows the composition of the flux-cored wires. Hardfacings were deposited onto SAE 1020 steel specimens of the size $120 \times 40 \times 10 \mathrm{~mm}^{3}$. Table 2 shows chemical compositions of the SAE 1020 steel, ferrotitanium and ferroboron in powder form as a filling material in the flux-cored wires. SAE 1020 steel surfaces to be coated were cleaned from dirt, rust, etc., by mechanical methods before the hardfacing process. In all welding processes, welding parameters were set as constant. Table 3 shows welding parameters.

Hardfacing processes were performed by three-pass welding and concerning the size of the welded layer as a $1.7 \mathrm{~mm}$ thick and $10 \mathrm{~mm}$ wide one that was obtained at a single pass. The specimens taken from the cross-section of hardfacing were subjected to process steps of standard metallographic grinding, polishing, and etching (2\% nital), respectively, in order to carry out microstructural examinations. Microstructure analysis was performed by optical microscopy (OM Nikon Eclipse-MA200i, Japan), scanning electron microscopy and EDX (SEM, Jeol JSM-7001F Inca X-Act, USA) analysis. X-ray (Bruker D8 Advance, Germany, $\mathrm{CuK} \alpha, 40 \mathrm{kV}-40 \mathrm{~mA}$, wavelength $1.54058 \mathrm{~nm}$ ) analysis was carried out to determine the phase composition of hardfacings. Both macrohardness (Rockwell C method, indentation load $150 \mathrm{kgf}$ (1471.5 N); EMCO Test Durascan) and microhard-
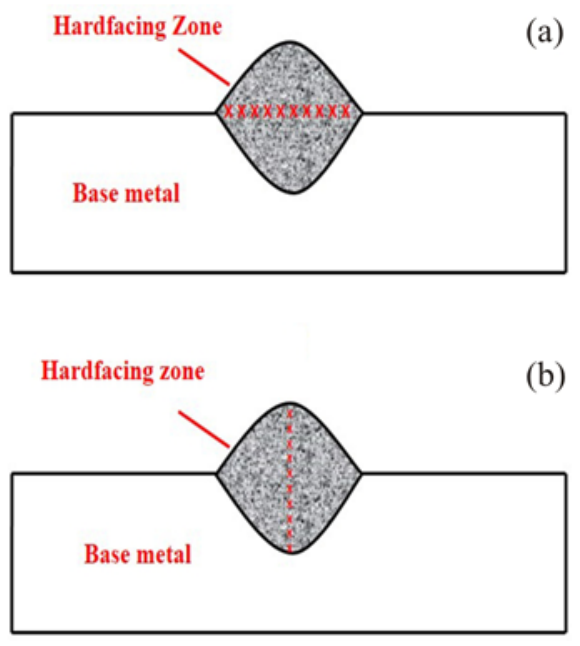

Fig. 1. Scheme of the microhardness measurements: (a) transversal section and (b) longitudinal section.

ness (Vickers method, indentation load $0.2 \mathrm{kgf}$ (1.8 $\mathrm{N})$; Leica microhardness tester, modified by Anton Paar) of the hardfacings were determined. Macrohardness was measured at the surfaces of the hardfacings, and the average value was calculated from 10 measurements. Microhardness was measured at the crosssections of the hardfacings both in the longitudinal and the transversal directions with the $1 \mathrm{~mm}$ distance between the imprints (Fig. 1). As seen in Fig. 1, in 


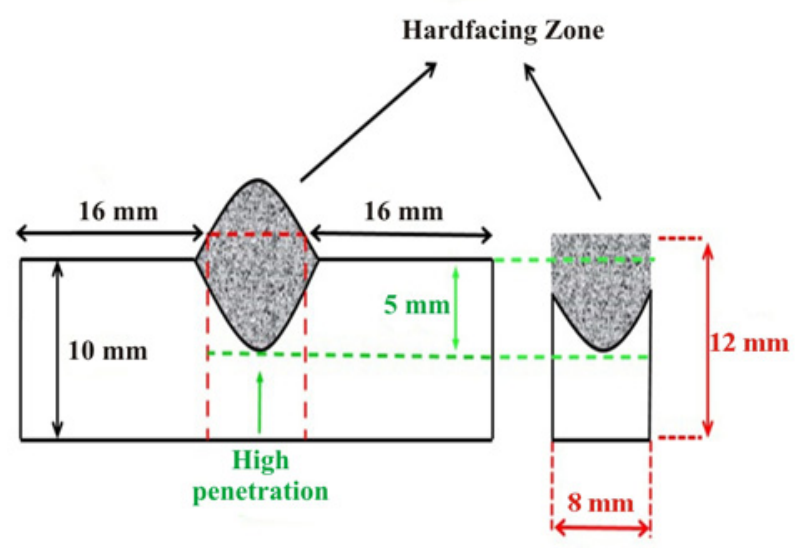

Fig. 2. Schematic overview of wear test samples.

order to evaluate the dilution effect on microhardness between hardfacing and dilution zone, penetration distance was set $5 \mathrm{~mm}$. The test specimens with sizes of $12 \times 8 \times 8 \mathrm{~mm}^{3}$ were prepared for wear test, and these specimens used with pin-on-disc method were subjected to abrasive wear tests. 10, 20, $30 \mathrm{~N}$ loads and 60 mesh abrasive sandpaper were used for wear tests (Fig. 2). Each test lasted $7 \mathrm{~min}$, and new abra- sive sandpaper was used for each test to obtain more objective results.

\section{Results and discussion}

\subsection{Composition and microstructure analysis}

Table 4 shows results of the chemical analysis carried out on the surface of the hardfacings. The increment of titanium and boron content occurred due to the increase of their amount in flux-cored wires, amounts of titanium and boron increased from 6.2 to $17.2 \mathrm{wt.} \%$ and from 3.1 to $7.5 \mathrm{wt} . \%$, respectively. While the lowest percentage of titanium and boron was obtained in the first hardfacing, the highest percentage of titanium and boron was obtained in the fourth hardfacing. This situation was designed during the production of flux-cored wires. With increasing percentage of boron and titanium in flux-cored wires, boron and titanium percentage in hardfacings were increased. On the other hand, hardfacings contained less titanium and boron than flux-cored wires, due to the dilution that occurred between the base metal and flux-cored wires. Unlike the titanium and boron percentages, carbon percentages were obtained between 0.15 and 0.19 wt.\%, which increased or decreased randomly. This carbon percentage was compatible with

Table 4. Chemical composition of hardfacings (wt.\%)

\begin{tabular}{ccccccccc}
\hline \multirow{3}{*}{ No. of specimen } & \multicolumn{8}{c}{ Composition (wt.\%) } \\
\cline { 2 - 9 } & $\mathrm{C}$ & $\mathrm{Mn}$ & $\mathrm{Si}$ & $\mathrm{P}$ & $\mathrm{S}$ & $\mathrm{Ti}$ & $\mathrm{B}$ & $\mathrm{Bal}$. \\
\hline 1 & 0.17 & 0.51 & 0.21 & 0.026 & 0.025 & 6.2 & 3.1 & $\mathrm{Fe}$ \\
2 & 0.14 & 0.62 & 0.23 & 0.028 & 0.027 & 8.8 & 4.6 & $\mathrm{Fe}$ \\
3 & 0.19 & 0.55 & 0.25 & 0.025 & 0.028 & 12.7 & 5.9 & $\mathrm{Fe}$ \\
4 & 0.15 & 0.59 & 0.20 & 0.029 & 0.026 & 17.2 & 7.5 & $\mathrm{Fe}$ \\
\hline
\end{tabular}

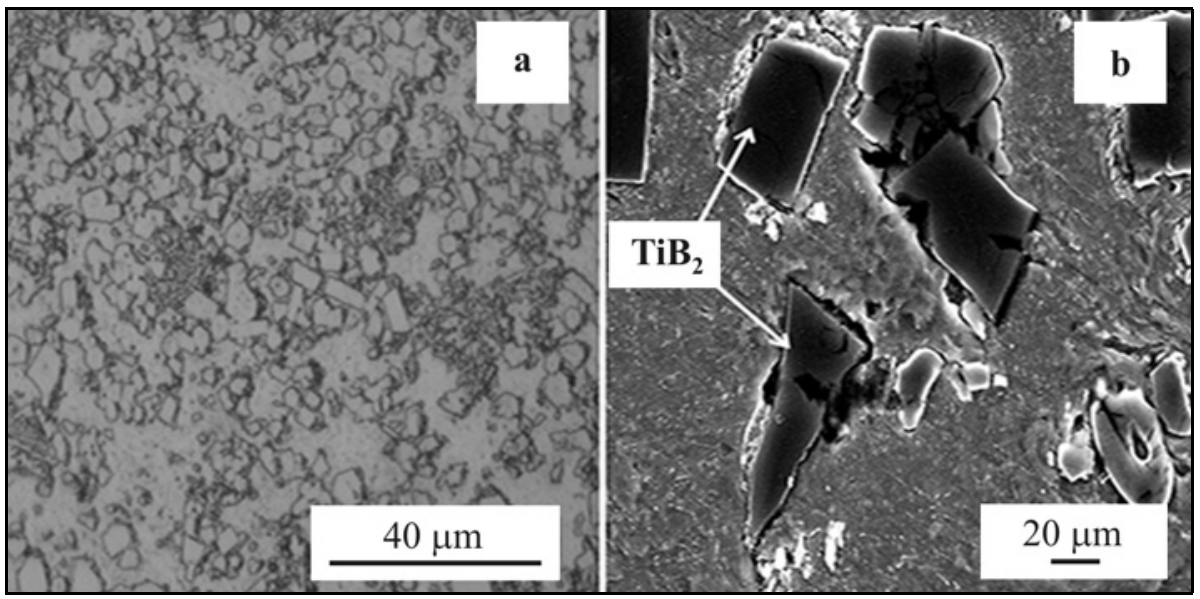

Fig. 3. Microstructure images of specimen no. 1: (a) OM, (b) SEM. 


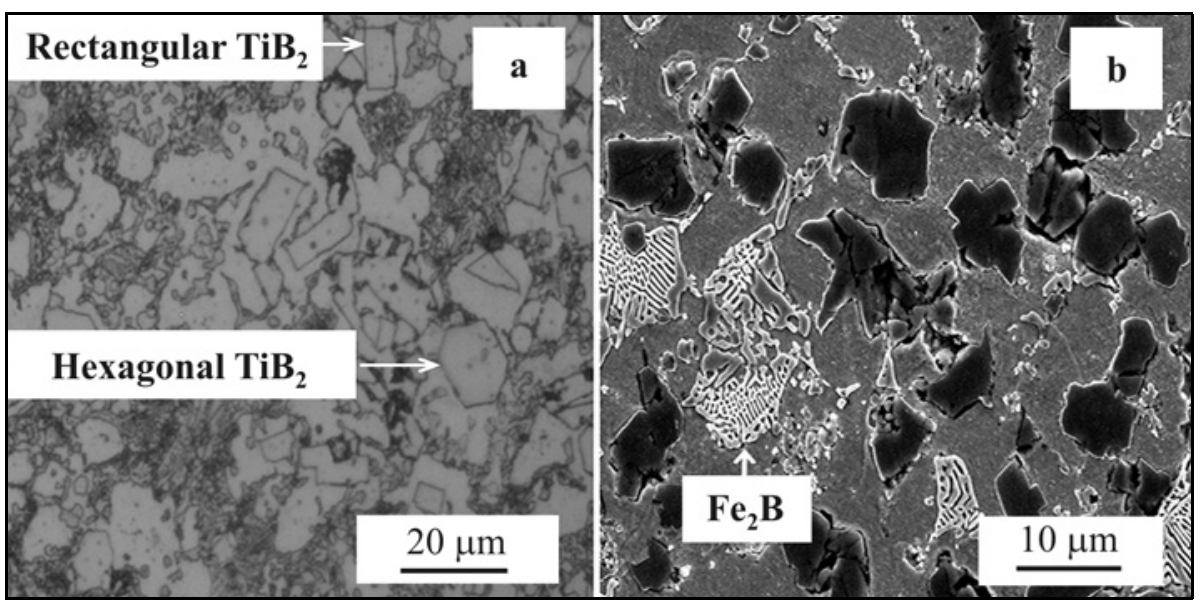

Fig. 4. Microstructure images of specimen no. 2: (a) OM, (b) SEM.

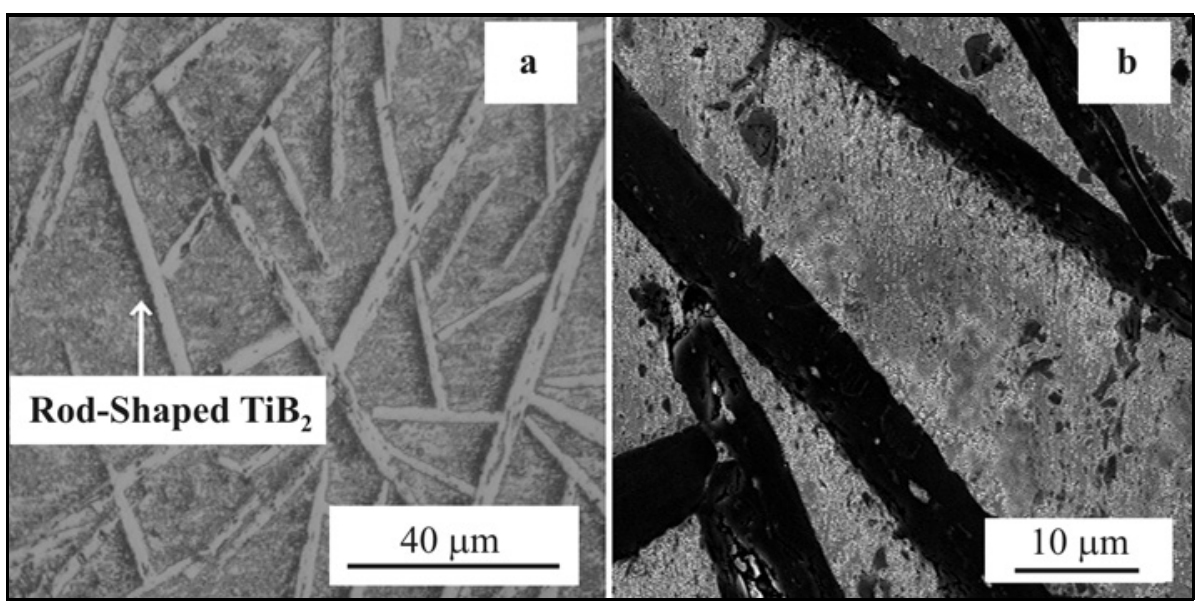

Fig. 5. Microstructure images of specimen no. 3: (a) OM, (b) SEM.

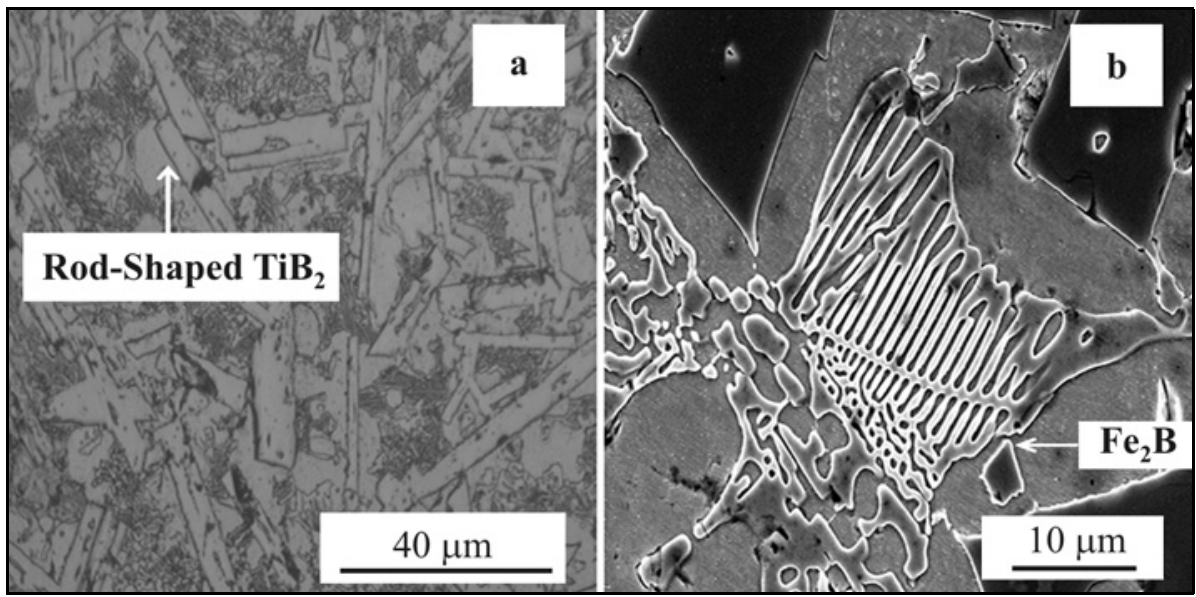

Fig. 6. Microstructure images of specimen no. 4: (a) OM, (b) SEM.

SAE 1020 steel, ferrotitanium, and ferroboron compositions before the welding process. Similarly, manganese, silicon, phosphorus, and sulfur elements were in trace quantity and close to each other in hardfacings.
Figures 3-6 show microstructure images of hardfacings. As is seen from the microstructure images, targeted $\mathrm{TiB}_{2}$ phases were obtained in all microstructures. This situation was supported by current studies in the literature $[3,19,20-25]$, EDX analysis results 

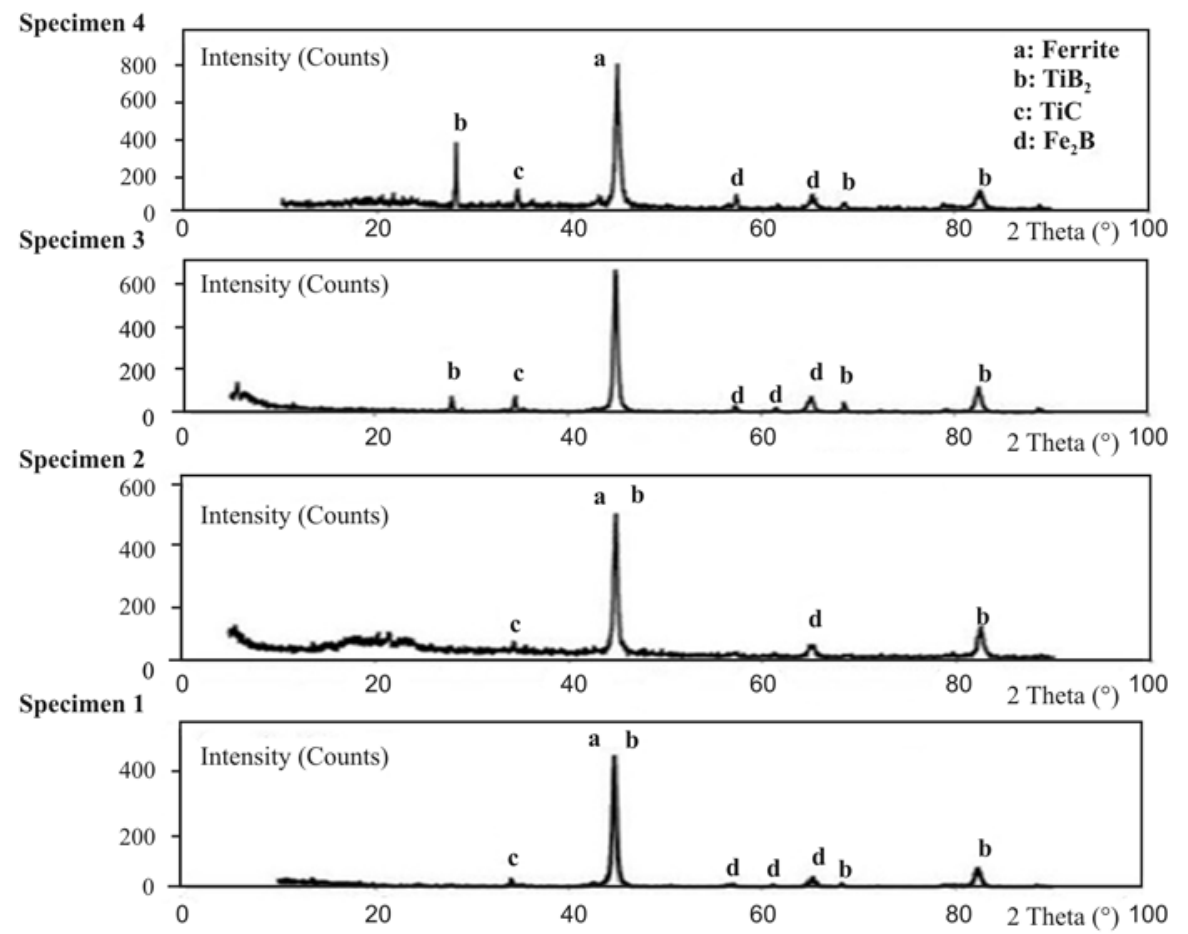

Fig. 7. X-Ray analysis results for hardfacings.

Table 5. Results of EDX analysis on $\mathrm{TiB}_{2}$ phases (wt.\%)

\begin{tabular}{ccccc}
\hline \multirow{2}{*}{ No. of specimen } & \multicolumn{4}{c}{ Composition (wt.\%) } \\
\cline { 2 - 5 } & $\mathrm{Ti}$ & $\mathrm{B}$ & $\mathrm{Mn}$ & $\mathrm{Fe}$ \\
\hline 1 & 63.20 & 25.10 & 0.03 & 11.67 \\
2 & 64.80 & 26.40 & 0.01 & 8.79 \\
3 & 66.90 & 28.70 & 0.03 & 4.37 \\
4 & 67.30 & 29.30 & 0.02 & 3.38 \\
\hline
\end{tabular}

(Table 5) and X-ray analysis results (Fig. 7) proved and supported the presence of $\mathrm{TiB}_{2}$ in hardfacings.

There was a significant difference between specimen no. 4 and the other specimens in terms of $\mathrm{TiB}_{2}$ crystal size and morphology. Namely, increasing the amount of ferrotitanium and ferroboron in hardfacings, $\mathrm{TiB}_{2}$ crystal size increased and morphology of $\mathrm{TiB}_{2}$ transformed from rectangular and hexagonal to rod-shaped whisker. At this point, the specimen no. 1 had the smallest $\mathrm{TiB}_{2}$ crystals size with rectangular and hexagonal morphology, and specimen no. 4 had the largest $\mathrm{TiB}_{2}$ crystals size with rod-shaped whisker morphology. So, it may be assumed that during synthesis the $\mathrm{TiB}_{2}$ crystals grow in the $\langle 001\rangle$ or in $\langle 002\rangle$ crystallographic direction and the growth is the most intensive in the case of the specimen no. 4. In addition to $\mathrm{TiB}_{2}$ phases in hardfacings, the presence of $\mathrm{TiC}$ and $\mathrm{Fe}_{2} \mathrm{~B}$ phases was determined by microstructural examinations and X-ray analysis.

Figure 8 shows volume fraction of the matrix and reinforcement phases in hardfacings. Reinforcement phases $\mathrm{TiB}_{2}$ and $\mathrm{Fe}_{2} \mathrm{~B}$, as well as the matrix phase $\alpha$ $\mathrm{Fe}$ (ferrite), were present in all the microstructures. In specimens no. 1 and 4, the formation of $\mathrm{TiB}_{2}$ phases was determined as 26.7 and 47.3 vol.\%, respectively, and the rest of the composition were determined as ferrite phase. In specimens no. 2 and $3, \mathrm{Fe}_{2} \mathrm{~B}$ phases were also available besides these phases. In specimens no. 2 and 3 , the formation of $\mathrm{TiB}_{2}$ phases was determined as 34.3 and $35 \mathrm{vol} \%$, and $\mathrm{Fe}_{2} \mathrm{~B}$ phases were determined as 7.9 and 15.9 vol.\%, respectively, and the rest of the composition was determined as ferrite phase. Based on these results, the volume fraction of $\mathrm{TiB}_{2}$ phases increased in all microstructures and volume fraction of $\mathrm{Fe}_{2} \mathrm{~B}$ phases dominated in specimens no. 2 and 3 with increasing rates. On the other hand, the volume fraction of the ferrite decreased in all microstructures except specimen no. 3. With the formation of $\mathrm{Fe}_{2} \mathrm{~B}$ phase in the specimens no. 2 and 3 , the volume fraction of ferrite decreased, while volume fraction of $\mathrm{TiB}_{2}$ increased. Compared to specimens no. 3 and 4 in terms of volume fraction of ferrite phases, specimen no. 4 had a greater fraction of ferrite phases than specimen no. 3. It may be assumed that volume fraction of $\mathrm{TiB}_{2}$ and ferrite matrix phases in hardfacings were affected by increasing the volume fraction of $\mathrm{Fe}_{2} \mathrm{~B}$ phases. 

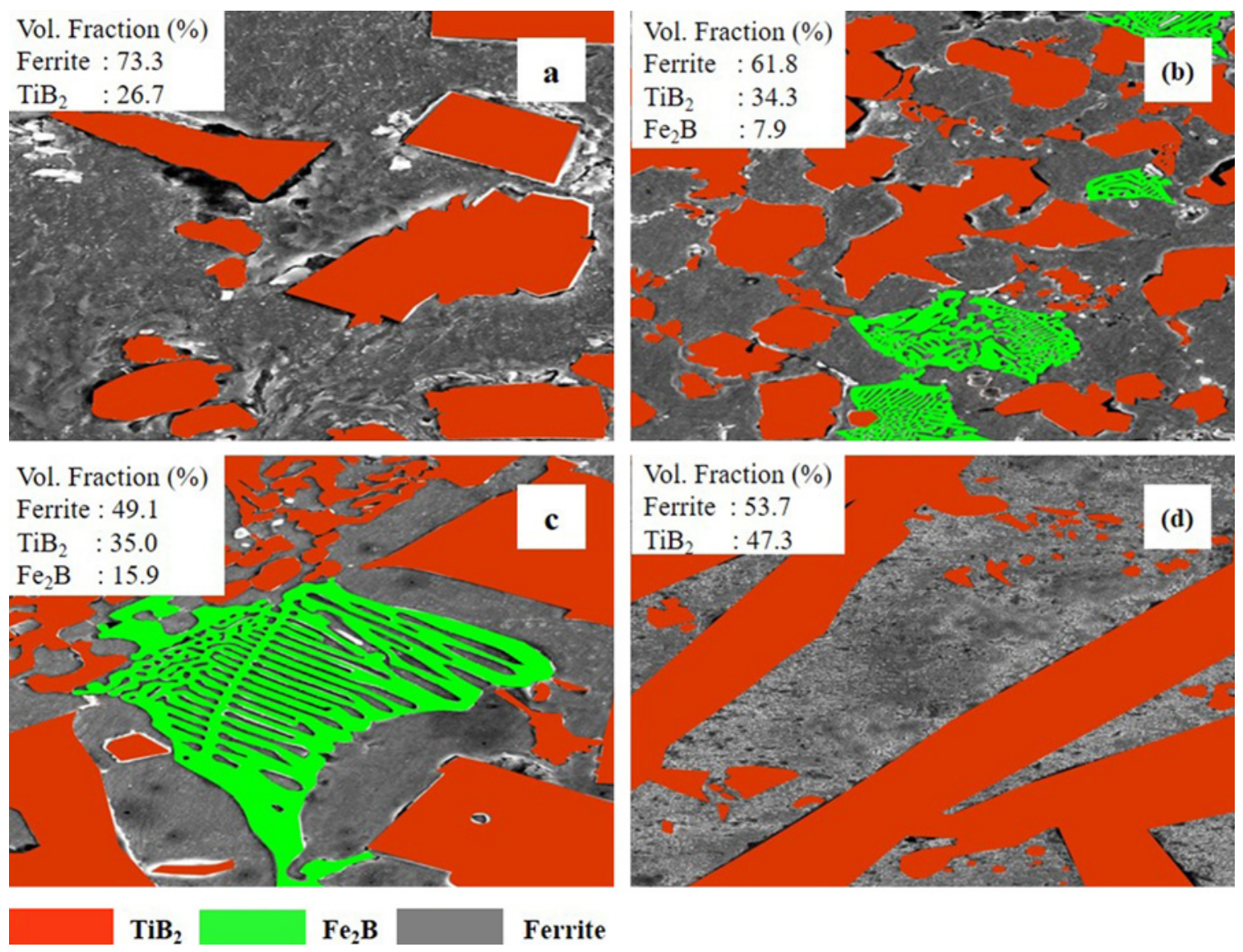

Fig. 8. The volume fraction of the matrix and reinforcement phases in hardfacings: (a) specimen no. 1, (b) specimen no. 2, (c) specimen no. 3 , and (d) specimen no. 4 .

Ta b le 6. Macrohardness results obtained by mean values

\begin{tabular}{cc}
\hline No. of specimen & Hardness, HRC \\
\hline 1 & $45 \pm 2$ \\
2 & $47 \pm 2$ \\
3 & $51 \pm 2$ \\
4 & $54 \pm 2$ \\
\hline
\end{tabular}

\subsection{Hardness measurements}

Table 6 shows macrohardness results and Figs. 910 show transversal and longitudinal microhardness results, respectively. According to the macrohardness results, the highest hardness result ( $54 \mathrm{HRC}$ ) was measured in specimen no. 4 and the lowest hardness result (45 HRC) was measured in specimen no. 1. These changes in hardness results were associated with increasing amount of ferrotitanium and ferroboron in flux-cored wires, change of $\mathrm{TiB}_{2}$ morphology in microstructures and increase of volume fraction of reinforcement phases such as $\mathrm{TiB}_{2}$ and $\mathrm{Fe}_{2} \mathrm{~B}$ in coated specimens. Macrohardness results were investigated

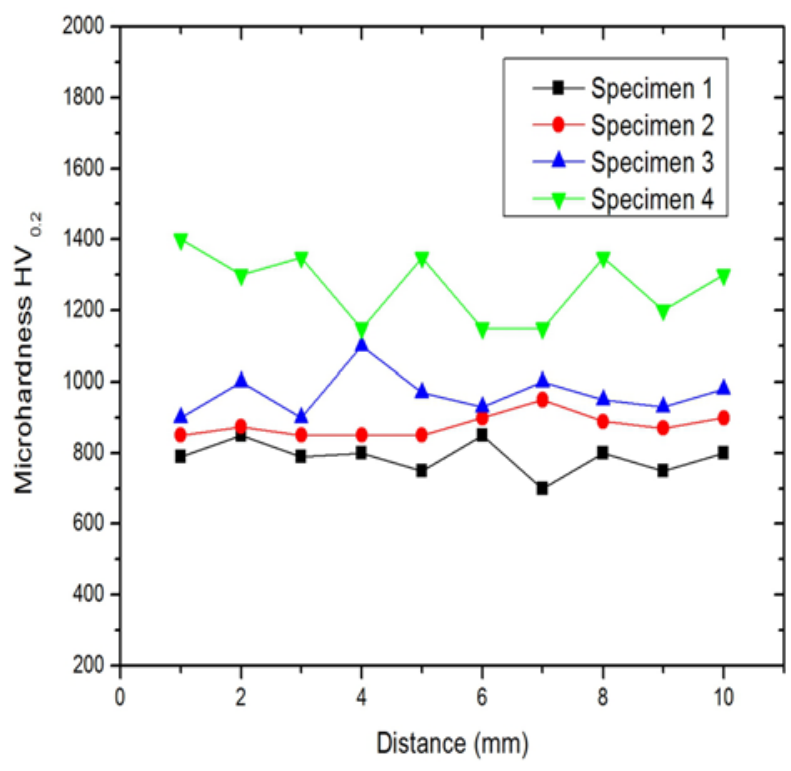

Fig. 9. Microhardness results for transversal measurements.

in detail; rectangular and hexagonal morphology of $\mathrm{TiB}_{2}$ phases dominated in first two specimens with 


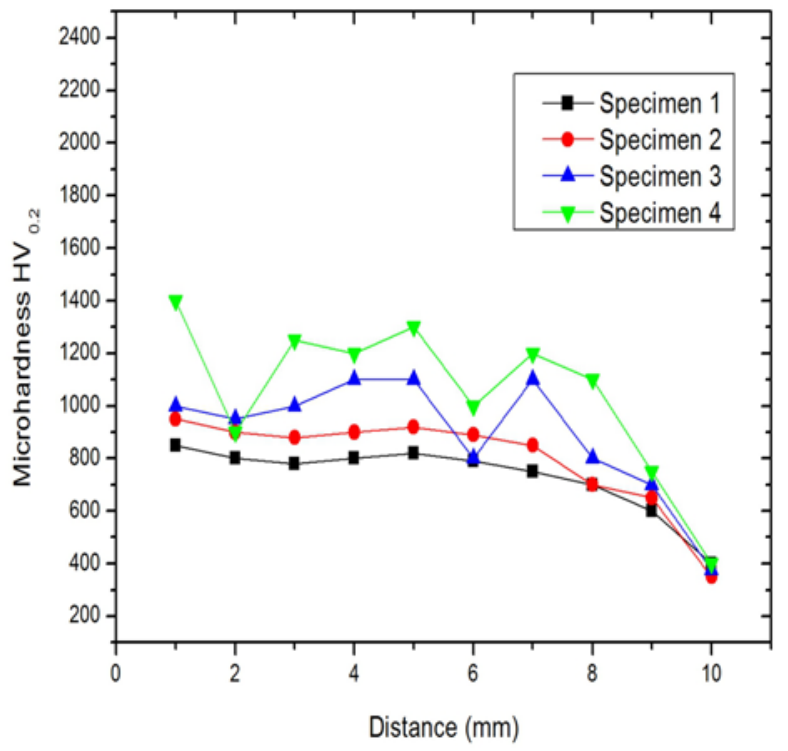

Fig. 10. Microhardness results for longitudinal measurements.

macrohardness results from $45 \mathrm{HRC}$ to $47 \mathrm{HRC}$, rectangular, hexagonal, and rod-shaped morphology of $\mathrm{TiB}_{2}$ phases dominated in third specimen with macrohardness result $51 \mathrm{HRC}$, and rod-shaped morphology of $\mathrm{TiB}_{2}$ phases dominated in the last specimen with macrohardness result $54 \mathrm{HRC}$. It may be assumed that morphology effect on macrohardness is minor due to the absence of the significant increase in hardness values with morphology change. Therefore, it can be said that major effect on macrohardness has an increase of volume fraction of reinforcement phases.

In transversal measurements, specimen no. 1 had the lowest microhardness values (700-850 $\mathrm{HV}_{0.2}$ ), specimens no. 2 and 3 exhibited higher microhardness values $\left(850-1100 \mathrm{HV}_{0.2}\right)$ than specimen no. 1 , but lower than specimen no. $4\left(800-1400 \mathrm{HV}_{0.2}\right)$. First two specimens showed homogeneous hardness distribution because of the low amount of $\mathrm{TiB}_{2}$ phases in hardfacing and homogeneous $\mathrm{TiB}_{2}$ distribution in ferrite matrix due to the smaller size of $\mathrm{TiB}_{2}$ phases. Microstructures were examined in specimens no. 3 and 4, two specimens also showed homogeneous distribution, notwithstanding the bigger size of $\mathrm{TiB}_{2}$ phases in hardfacing. However, specimens no. 3 and 4 showed microhardness fluctuation, unlike the first two specimens. It was considered that this microhardness fluctuation was associated with the bigger size of $\mathrm{TiB}_{2}$ phases, and accordingly hardness trace between ferrite and $\mathrm{TiB}_{2}$ phases due to the microhardness indent size. Namely, when the indentor hits a $\mathrm{TiB}_{2}$ particle or a region in its proximity, the microhardness value is high, and when the indentor hits a ferrite region between two $\mathrm{TiB}_{2}$ particles, the microhardness value is low.

In longitudinal microhardness results, specimens no. 1 and 2 had a microhardness values between 400$900 \mathrm{HV}_{0.2}$ and specimens no. 3 and 4 had a microhardness values between 400-1400 $\mathrm{HV}_{0.2}$. Compared with transversal microhardness measurements, longitudinal microhardness values were similar to each other except for those taken from the hardfacing boundary and measured as $400 \mathrm{HV}_{0.2}$. In the same way, specimens no. 1 and 2 showed more homogeneous microhardness values compared to specimens no. 3 and 4 as well as transversal measurements. Microhardness results taken from hardfacing boundary decreased from 800 to $400 \mathrm{HV}_{0.2}$ due to the decreasing amount of reinforcement phases. Likewise, it was determined that longitudinal microhardness values partially decreased approaching the hardfacing boundary. Lastly, macrohardness results measured by using Rockwell-C (HRC) scale and microhardness results measured by using Vickers $\mathrm{HV}_{0.2}$ scale were compared with current studies in literature; these results were in good agreement [3, 19-22, 24, 26-28].

\subsection{Abrasive wear assessment}

Figure 11 shows abrasion wear loss results. As shown in Fig. 11, specimen no. 4 had the lowest wear loss and specimen no. 1 had the highest wear loss for all loads. This condition was substantially associated with structure morphology of $\mathrm{TiB}_{2}$ and increasing the volume fraction of reinforcement phase such as $\mathrm{TiB}_{2}$ and $\mathrm{Fe}_{2} \mathrm{~B}$ in hardfacings $[7,9,14,23,26,27,29]$. In addition to these results, wear losses increased with the increase in applied loads. Increasing of the wear losses due to the increasing applied loads was an expected result because of the increased plastic deformation between abrasive paper and hardfacing surface [30]. 


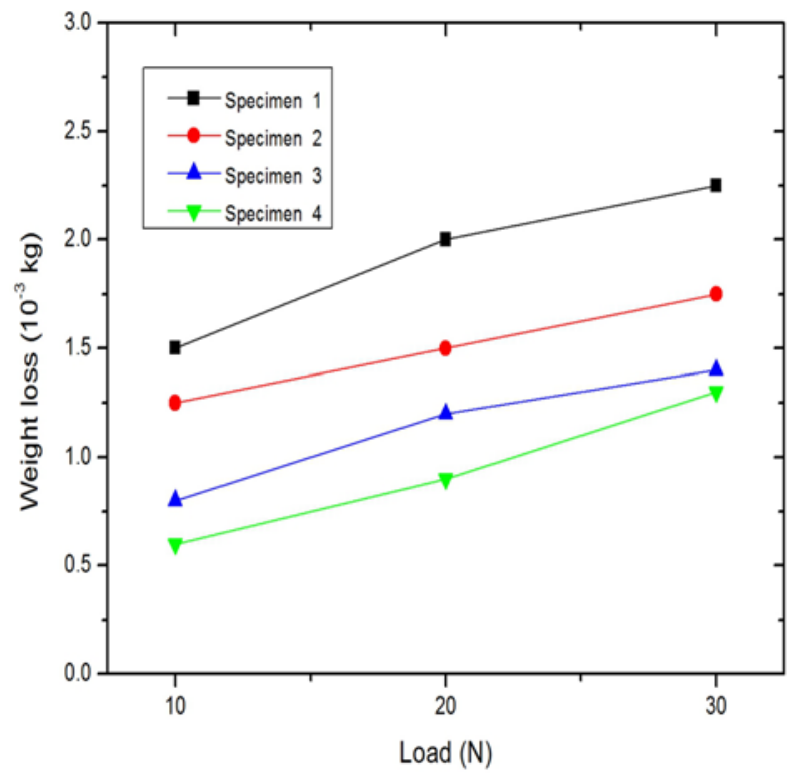

Fig. 11. Abrasive wear test results.

Figure 12 shows SEM images of abrasive wear surface under $20 \mathrm{~N}$ load. Wear behavior mechanism was micro-ploughing and micro-cutting in general. In addition to these results, specimen no. 1 had deep, large, and continuous abrasive wear scratches. When proceeding from specimen no. 1 to specimen no. 4, wear scratches were changed to shallow, narrow and discontinuous scratches. According to these conditions, abrasive particles were not enabled to insert and scratch sufficiently due to the increasing volume fraction of $\mathrm{TiB}_{2}$ and consequently increasing of hardness. It is well known that hardness results and abrasive wear resistance are directly proportional to each other. With the increase in hardness, wear resistance increases or wear loss decreases as in this study.

\section{Conclusions}

The surface of SAE 1020 steel was coated by using tungsten inert gas welding with flux cored wires containing ferrotitanium and ferroboron. The following results were obtained:

1. Targeted $\mathrm{TiB}_{2}$ phases were formed in all hardfacings; $\mathrm{Fe}_{2} \mathrm{~B}$, TiC, and ferrite phases were determined as well.

2. With the increasing proportion of titanium

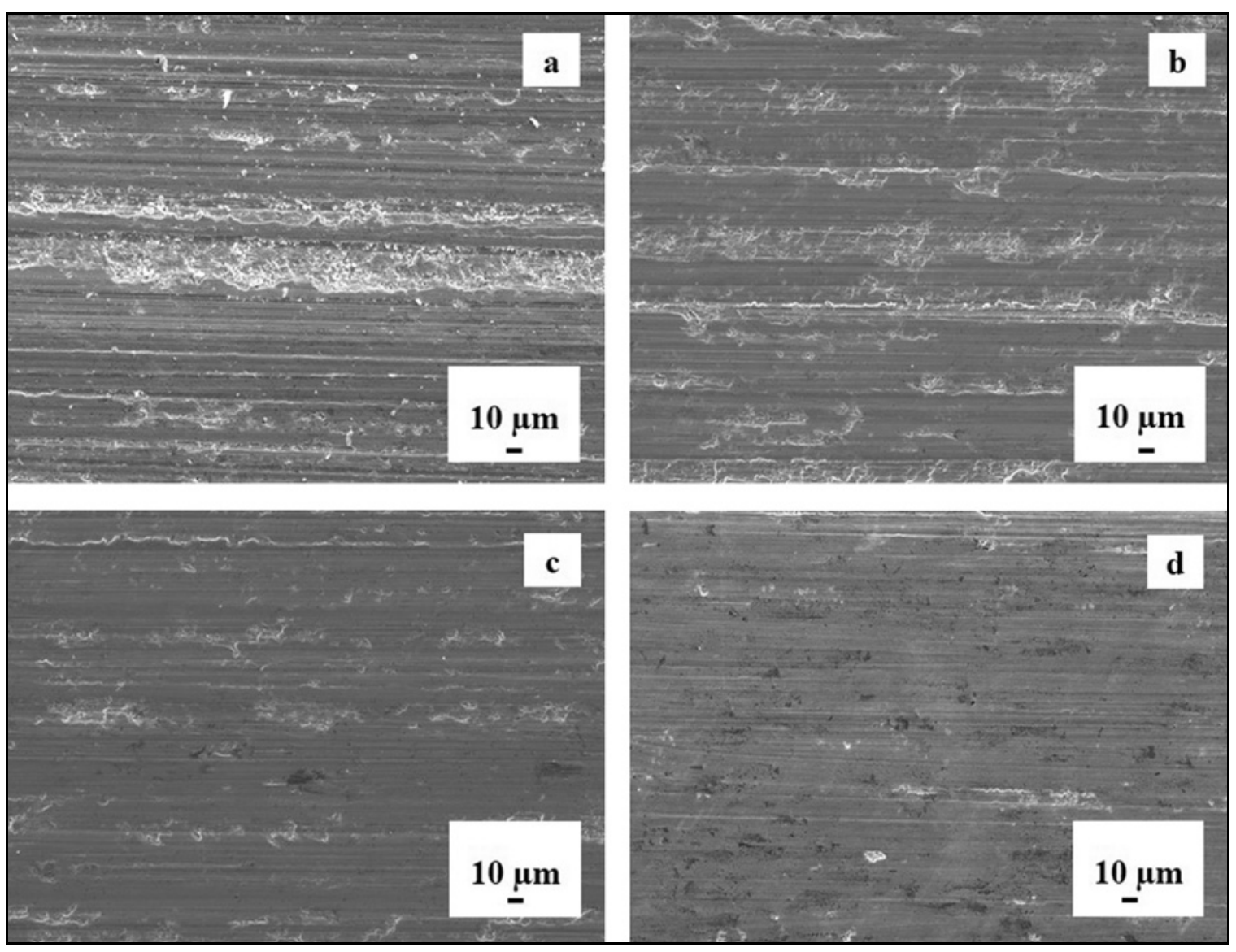

Fig. 12. Scanning electron microscopy (SEM) images of abraded surfaces (load $20 \mathrm{~N}$ ): (a) specimen no. 1, (b) specimen no. 2, (c) specimen no. 3 , and (d) specimen no. 4. 
and boron in flux-cored wires, the morphology of $\mathrm{TiB}_{2}$ changed from rectangular and hexagonal to rodshaped whisker. Rod-shape whisker morphology of $\mathrm{TiB}_{2}$ dominated with 17.2 wt.\% titanium and 7.5 wt. $\%$ boron in specimen no. 4 , the rectangular and hexagonal morphology of $\mathrm{TiB}_{2}$ dominated with 6.2 wt. $\%$ titanium and 3.1 wt. $\%$ boron in specimen no. 1 .

3 . Due to the increasing proportion of ferrotitanium and ferroboron in the flux-cored wire, macrohardness of the hardfacings increased from 45 to 54 HRC proportionally to the increasing amount of $\mathrm{TiB}_{2}$ phase from 26.7 to $47.3 \mathrm{vol} . \%$ in hardfacings.

4. While wear losses decreased with the increase in titanium and boron in the flux-cored wire, wear losses increased with the increase in applied loads.

5 . According to the hardness and abrasive wear test results, the lowest wear loss, and the highest macroand microhardness results were obtained in hardfacing no. 4 which contained $47.3 \mathrm{vol} . \% \mathrm{TiB}_{2}$ phase.

\section{Acknowledgements}

This study was supported by a grant from the Firat University Scientific Research Projects Unit (FUBAP-1994) in Turkey. The authors would like to acknowledge all laboratory staff and colleagues for their support to this study and thank our friends for their physical or mental contributions.

\section{References}

[1] Tjong, S. C., Ma, Z. Y.: Mater. Sci. Eng. R. Rep., 29, 2000, p. 49. doi:10.1016/S0927-796X(00)00024-3

[2] Lu, L., Lai, M. O., Chen, L. F.: Acta Mater., 45, 1997, p. 4297. doi:10.1016/S1359-6454(97)00075-X

[3] Farid, A., Guo, S., Cui, F., Feng, P., Lin, T.: Mater. Lett., 61, 2007, p. 189. doi:10.1016/i.matlet.2006.04.028

[4] Wang, H. Y., Jiang, Q. C., Ma, B. X., Wang, Y., Zhao, F.: J. Alloys Compd., 391, 2005, p. 55. doi:10.1016/j.jallcom.2004.08.045

[5] Yi, D., Yu, P., Hu, B., Liu, H., Wang, B., Jiang, Y.: Mat. Des., 52, 2013, p. 572. doi:10.1016/j.matdes.2013.05.097

[6] Song, B., Dong, S., Liao, H., Coddet, C.: Surf. Coat. Tech., 268, 2015, p. 24. doi:10.1016/j.surfcoat.2014.06.055

[7] Liu, J., Yang, S., Xia, W., Jiang, X., Gui, C.: J. Alloys and Compd., 654, 2016, p. 63. doi:10.1016/i.jallcom.2015.09.130

[8] Zhong, L., Zhang, X., Chen, S., Xu, Y., Wu, H., Wang, J.: Inter. J. Refr. Met. and Hard Mater., 57, 2016, p. 42. doi:10.1016/j.ijrmhm.2016.02.001

[9] He, P., Huang, S., Huang, Z., Pan, C., Zou, J., Zhang, Y., Wang, H., Cheng, X., Hu, J., Wang, H.: Surf. Coat. Tech., 266, 2015, p. 134 . doi:10.1016/i.surfcoat.2015.02.031
[10] Sharifitabar, M., Khaki, J. V., Sabzevar, M. H.: Surf. Coat. Tech., 285, 2016, p. 47. doi:10.1016/j.surfcoat.2015.11.019

[11] Tan, H., Luo, Z., Li, Y., Yan, F., Duan, R., Huang, Y.: Wear, 324-325, 2015, p. 36. doi:10.1016/j.wear.2014.11.023

[12] Jankauskas, V., Antonov, M., Varnauskas, V., Skirkus, R., Goljandin, D.: Wear, 328-329, 2015, p. 378. doi:10.1016/i.wear.2015.02.063

[13] Kwok, C. T., Man, H. C., Cheng, F. T.: Scripta Mater., 39, 1998, p. 1229. doi: 10.1016/S1359-6462(98)00308-X

[14] Hou, Q. Y., Luo, L. M., Huang, Z. Y., Wang, P., Ding, T. T., Wu, Y. C.: Surf. Coat. Tech., 283, 2015, p. 52. doi:10.1016/j.surfcoat.2015.10.059

[15] Sudah, C., Shankar, P., Rao, R. V., Thirumurugesan, R., Vijayalakshmi, M., Raj, B.: Surf. Coat. Tech., 202, 2008, p. 2103. doi:10.1016/i.surfcoat.2007.08.063

[16] Nayak, S. S., Biro, E., Zhou, Y.: Welding and Joining of Advanced High Strength Steels (AHSS). Cambridge, Woodhead Publishing 2015. doi:10.1016/B978-0-85709-436-0.00005-9

[17] Baoshuai, D., Sameer, R. P., Narendra, B. D.: Script. Mater., 59, 2008, p. 1147. doi:10.1016/j.scriptamat.2008.07.035

[18] Davis, J. R.: ASM Handbook: Welding, Brazing and Soldering. Materials Park, ASM International 1993.

[19] Wang, Y., Zhang, H. Y., Wang, B. X., Ma, Q. C.: Mater. Sci. Eng., 422, 2006, p. 339. doi:10.1016/j.msea.2006.02.012

[20] Animesh, A., Bandyopadhyay, T. K., Das, K.: J. Mater. Process. Tech., 172, 2006, p. 70. doi:10.1016/j.jmatprotec.2005.09.011

[21] Jiang, Q. C., Ma, B. X., Wang, H. Y., Wang, Y., Dong, Y. P.: Composites, 37, 2006, p. 133. doi:10.1016/j.compositesa.2005.03.011

[22] Darabara, M., Papadimitriou, G. D., Bourithis, L.: Surf. Coat. Tech., 201, 2006, p. 3518. doi:10.1016/j.surfcoat.2006.08.105

[23] Zhang, P., Wang, X., Guo, L., Cai, L., Sun, H.: App. Surf. Sci., 258, 2011, p. 1592. doi:10.1016/j.apsusc.2011.10.004

[24] Du, B., Paital, S. R., Dahotre, N. B.: Optics \& Las. Techn., 45, 2013, p. 643. doi:10.1016/j.optlastec.2012.05.017

[25] Lin, H., Ying, L., Jun, L., Binghong, L.: Rare Met. Mat. and Eng., 43, 2014, p. 283. doi:10.1016/S1875-5372(14)60059-X

[26] Yilmaz, S. O., Ozenbas, M., Yaz, M.: Tribol. Int., 42, 2009, p. 1220. doi:10.1016/j.triboint.2009.04.041

[27] Tang, J.: App. Surf. Sci., 365, 2016, p. 202. doi:10.1016/j.apsusc.2015.12.198

[28] Meng, J., Ji, Z.: Physics. Procedia, 50, 2013, p. 253. doi:10.1016/j.phpro.2013.11.040

[29] Buchley, M. F., Gutierrez, J. C., Leon, L. M., Toro, A.: Wear, 259, 2005, p. 52. doi:10.1016/j.wear.2005.03.002

[30] Coronado, J. J., Sinatora, A.: Wear, 267, 2009, p. 6. doi:10.1016/j.wear.2008.12.071 